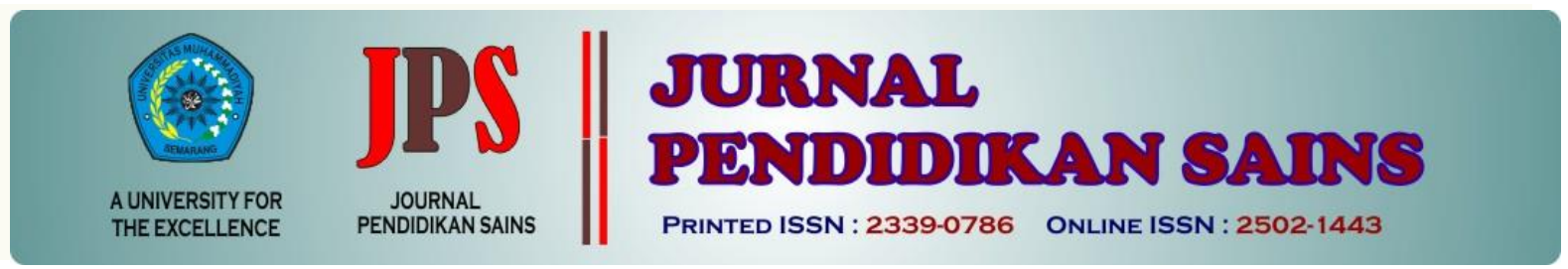

http://jurnal.unimus.ac.id/index.php/JPKIMIA

\title{
PENGEMBANGAN BUKU AJAR FISIKA OPTIK BERBASIS SOFT-SKILLS
}

\author{
Oleh: \\ Setya Ferywidyastuti \\ STIKES HAKLI Semarang \\ setya_ferywidyastuti@yahoo.com
}

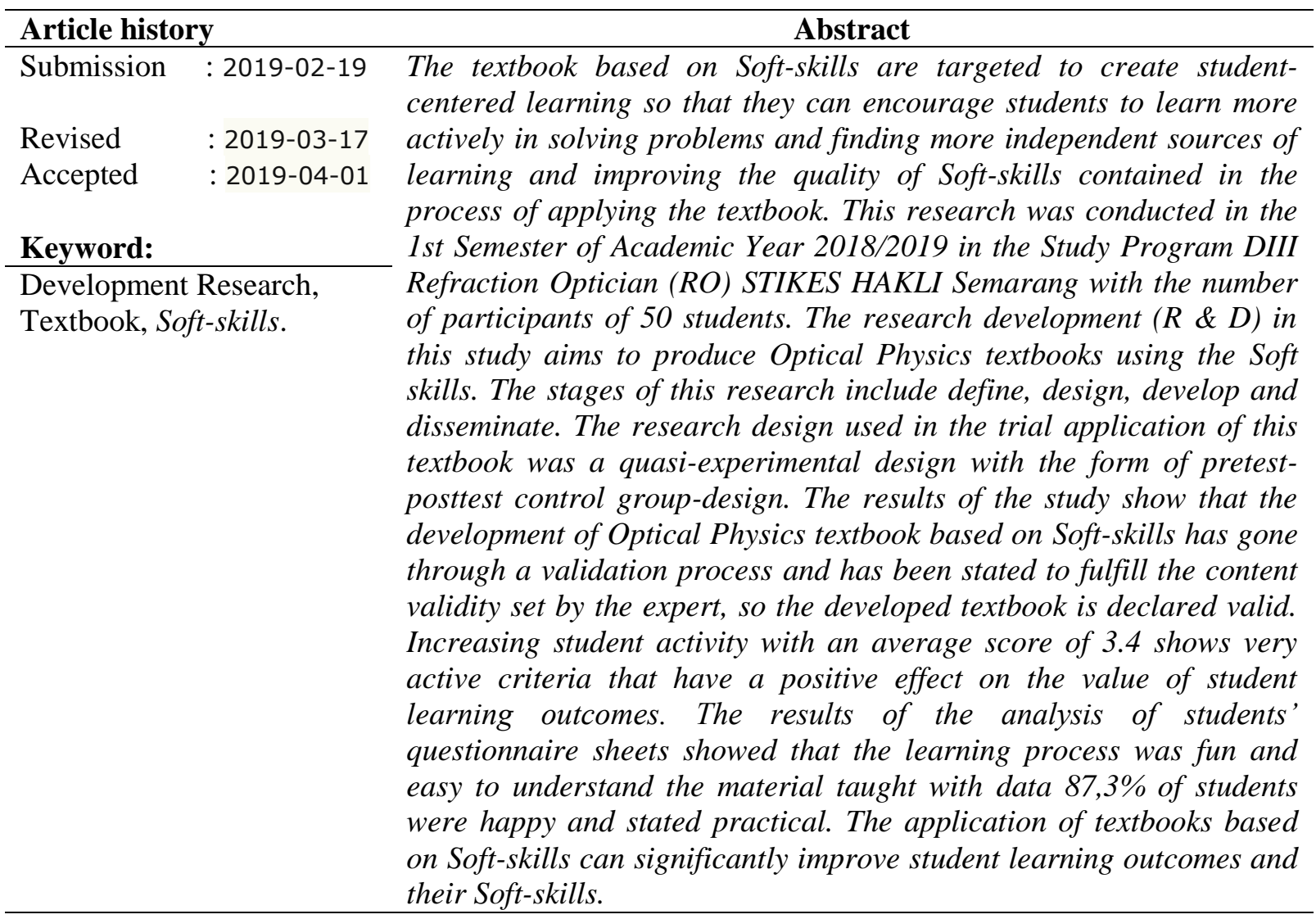

\section{Pendahuluan}

Dunia pendidikan memiliki tanggung jawab untuk menghasilkan lulusan yang profesional dan mampu bersaing di dunia kerja dengan berbekal Soft-skills dan hard skills yang memadai. Peningkatan kompetensi hard skills harus diimbangi juga dengan dengan peningkatan Soft-skills untuk meningkatkan profesionalisme tenaga kerja (Ismail, 2007). Hasil penelitian dari Christian di Institut Teknologi Carnegie menunjukan bahwa dari sepuluh ribu orang sukses, hanya 15\% ditentukan oleh hard skills, sedangkan sebanyak $85 \%$ sangat dipengaruhi oleh Softskills (Hartiti, 2013). Soft-skills adalah keterampilan yang melibatkan hubungan antara

*Corresponding Author:

Nama : Setya Ferywidyastuti

Lembaga : STIKES HAKLI Semarang

Email : setya_ferywidyastuti@yahoo.com 
seseorang dan sosial sebagai perilaku pribadi dan interpersonal yang mengembangkan dan memaksimalkan kinerja manusia (Junrat et al., 2014), maka Soft-skills ini berperan penting untuk mendukung keberhasilan dalam bekerja.

Berdasarkan hasil penelitian tersebut, tenaga pendidik mempunyai tantangan untuk merancang proses pembelajaran yang membekali siswa tidak hanya aspek hard skills yang berorientasi pada pemahaman materi secara kognitif, akan tetapi membekali peserta didik dengan keterampilan Soft-skills. Tantangan lain dalam proses pembelajaran Fisika, khususnya Fisika Optik adalah mata kuliah wajib yang diajarkan di Program Studi DIII Refraksi Optisi (RO) STIKES HAKLI Semarang adalah mahasiswa kurang menyukai pelajaran tersebut dan menganggap mata kuliah tersebut sulit. Pengajar dituntut untuk merancang perangkat pembelajaran yang menantang dan berpusat pada keterlibatan siswa. Perangkat pembelajaran yang sangat mendukung proses pembelajaran adalah tersedianya buku ajar. Supriadi menyimpulkan bahwa buku ajar berpengaruh sekitar $75 \%$ terhadap capaian pembelajaran (Supriadi, 2001). Buku ajar juga merupakan media yang tepat untuk memfasilitasi peserta didik untuk mereview kembali materi yang sudah diajarkan karena semua materi yang akan diajarkan dalam satu semester sudah tersusun dengan sistematis (Muslich, 2010).

Solusi yang berdasarkan tantangan tersebut adalah perlunya disusun buku ajar berbasis Soft-skills yang berpusat pada siswa sehingga mereka dapat memecahkan masalah dalam kelompok dan merefleksikan pengalaman mereka (Selçuk \& Çalişkan, 2010), dan lebih aktif dalam menciptakan konsep secara mandiri dan memiliki kemampuan komunikasi, keterampilan memecahkan masalah, managemen waktu, inisiatif, dan kerjasama.

Peningkatan keterampilan Soft-skills sangat dibutuhkan dalam dunia kerja. Soft-skills adalah keterampilan yang melibatkan hubungan antara seseorang dan sosial sebagai perilaku pribadi dan interpersonal yang mengembangkan dan memaksimalkan kinerja manusia (Junrat et al., 2014), maka Soft-skills ini berperan penting untuk mendukung keberhasilan dalam bekerja. Kualitas hard skill harus dilengkapi dengan kualitas Soft-skills untuk meningkatkan profesionalisme mereka (Ismail, 2007). Penelitian sumber daya manusia yang dilakukan oleh by Emotional Quality Inventory (EQI) institution menyatakan bahwa pekerja profesional di seluruh dunia menunjukkan bahwa IQ hanya menyumbang maksimal $15 \%$ dibandingkan dengan EQ atau Soft-skills dan 85\% dipengaruhi oleh Soft-skills (Hartiti, 2013). Soft-skills meliputi kesadaran diri, kepercayaan, kesadaran, kemampuan beradaptasi, berpikir kritis, kesadaran organisasi, sikap, inisiatif, empati, kepercayaan diri, integritas, pengendalian diri, kepemimpinan, pemecahan masalah, pengambilan risiko dan manajemen waktu. Penelitian lain menunjukan ada enam Soft-skills yang sangat mendukung kesuksesan dalam dunia kerja adalah communication skills, critical and creative thinking, inquiry/reasoning skills, interpersonal skills, multicultural/ multilingual literacy, problem solving (Widarto et al., 2013), dan Soft-skills seperti pengambilan keputusan, penyelesaian masalah, mengelola konflik, kerja tim dan menjadi inovatif adalah elemen penting dalam menghadapi persaing kerja (Musa et al., 2012).

Soft-skills yang akan diintegrasikan dalam pengembangan buku ajar pada penelitian ini meliputi kemampuan komunikasi, keterampilan memecahkan masalah, managemen waktu, inisiatif, dan kerjasama. Alat untuk mengevaluasi Soft-skills yang bisa diimplementasikan dalam penelitian ini adalah self-report dan checklist (Widhiarso, 2009). Self report merupakan sekumpulan stimulus berupa pernyataan, pertanyaan atau daftar deskripsi diri yang direspon oleh individu. Checklist lebih tepat dipakai untuk mengukur dimensi perilaku mahasiswa misalnya cara mempresentasikan makalah, cara berinteraksi dengan orang lain, atau strategi mengatasi masalah. Teknik peer evaluation antar mahasiswa biasanya menggunakan checklist.

Buku ajar merupakan naskah yang berisi kumpulan materi yang ditulis dan disusun oleh pengajar sesuai dengan rencana materi yang mereka ajarkan (Deepublish, 2016), oleh karena itu buku ajar merupakan salah satu faktor yang mempengaruhi prestasi belajar siswa. Supriadi menyimpulkan bahwa buku ajar berpengaruh sekitar $75 \%$ terhadap capaian pembelajaran (Supriadi, 2001), maka para pengajar dituntut untuk menyusun buku ajar sehingga pengajarannya lebih terarah dan sistematis. Indikator penyusunan buku ajar meliputi materi terpilih, diseleksi, divalidasi ahli, sistematis, menyesuaikan strategi pembelajaran, digunakan sesuai dengan tingkat pendidikan peserta didik, dan mematuhi kaidahkaidah penulisan (Muslich, 2010). Buku ajar 
juga harus memiliki "sudut pandang yang jelas, sumber yang jelas, pendekatan, metode dan teknik yang digunakan juga harus jelas"(Deepublish, 2016).

Prinsip pengembangan buku ajar yang akan dilakukan meliputi tiga faktor yaitu standar materi, standar penyajian dan standar bahasa (Hanifah, 2014). Standar materi adalah standar yang berkaitan dengan materi yang akan diajarkan terkait dengan keakuratan, kemutakhiran, dan sistematis. Standar penyajian adalah standar yang berhubungan dengan penyajian per bab, anatomi buku ajar, kode etik dan hak cipta. Standar bahasa merupakan penggunaan bahasa yang mempertimbangkan aspek kejelasan, kesesuaian, dan keterbacaan.

Buku ajar yang dikembangkan dalam penelitian ini untuk perkuliahan Fisika Optik. Fisika adalah bagian dari sains yang menyangkut pengetahuan, fakta, konsep, teori, dan prinsip yang mengarah pada produk sains (Linuwih et al., 2017). Fisika optik merupakan bagian dari Fisika yang fokus pada studi tentang sifat-sifat dasar cahaya dan interaksinya terhadap materi yang meliputi materi fenomena optik klasik seperti refleksi, diffraction dan interference, dan mempelajari quantum mechanical properties seperti photons. Fisika optik adalah mata kuliah wajib yang diajarkan di Program Studi DIII Refraksi Optisi (RO) STIKES HAKLI Semarang. Topik yang disusun dalam penelitian pengembangan buku ajar ini meliputi hukum pemantulan, pembentukan bayangan pada cermin datar, cermin cekung, cermin cembung, hukum pembiasan, pembentukan bayangan pada lensa mata, lensa cekung, lensa cembung, mata normal, rabun dekat, rabun jauh, silindris, dan perbandingan mata dengan kamera.

Tujuan penelitian ini adalah mengembangkan buku ajar Fisika Optik berbasis Soft-skills untuk meningkatkan aktivitas mahasiswa.

\section{Metode Penelitian}

Penelitian ini dilaksanakan pada Semester 1 Tahun Akademik 2018/2019 di Prodi DIII Refraksi Optisi (RO) STIKES HAKLI Semarang dengan jumlah partisipan 50 orang mahasiswa. Penelitian pengembangan (R\&D) dalam penelitian ini bertujuan untuk menghasilkan buku ajar materi Fisika Optik berbasis Soft-skills. Pengembangan perangkat pembelajaran menggunakan model pengembangan yang dikemukakan oleh
Thiagarajan, Sammel dan Sammel (1997) dalam Trianto (2012) yang dikenal dengan sebutan Four-D Model (Model 4-D), yaitu define (pendefinisian/ penetapan), design (perancangan), develop (pengembangan) dan disseminate (penyebaran).

Tahapan penelitian berdasarkan ini meliputi define, design, develop dan disseminate yang dapat dilihat pada Gambar 1 . Desain penelitian yang digunakan dalam uji coba pemakaian ini adalah quasi experimental Design dengan bentuk pretest-postest control group-design.

\section{Perencanaan (Define)}

Langkah-langkah dalam tahap perencanaan ini adalah analisis awal, analisis peserta didik, analisis konsep, analisis tugas, dan perumusan tujuan pembelajaran. Analisis awal bertujuan untuk memunculkan masalah mendasar yang diperlukan dalam pengembangan buku ajar materi Fisika Optik yang akan diteliti. Tahap ini kegiatan yang dilakukan yaitu dengan mengkaji teori belajar yang mendukung dengan tuntutan masa depan sehingga diperoleh gambaran pola pembelajaran yang dianggap ideal.

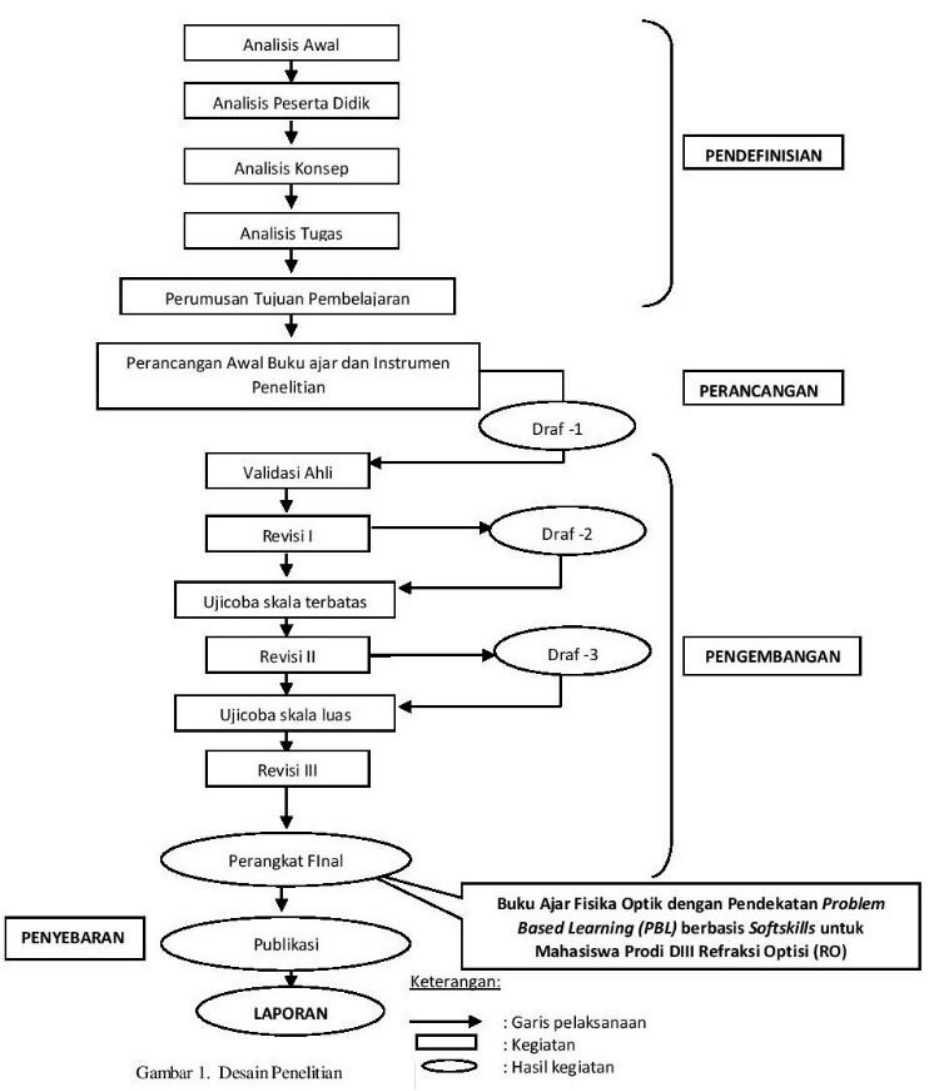

Gambar 1. Desain Penelitian 
Analisis peserta didik bertujuan untuk menelaah tentang karakteristik peserta didik yang sesuai dengan rancangan dan pengembangan bahan pembelajaran. Karakteristik ini meliputi kemampuan dan latar belakang pengetahuan, sikap dan topik pembelajaran, pemilihan media, pemilihan format, bahasa yang digunakan dan perkembangan kognitif peserta didik.

Analisis konsep digunakan untuk mengidentifikasi bagian-bagian utama yang akan diajarkan dan menyusunnya secara sistematis. Analisis tugas mencakup kumpulan prosedur untuk menentukan isi materi Fisika Optik dalam bentuk garis besar yang akan disusun dalam buku ajar.

Perumusan tujuan pembelajaran bertujuan untuk mengkonversikan antara analisis konsep dan analisis tugas menjadi tujuan-tujuan pembelajaran yang dinyatakan dengan tingkah laku.

\section{Perancangan (Design)}

Tujuan dari tahap ini adalah merancang buku ajar dan instrumen penelitian Fisika Optik berbasis Soft-skills. Tahap ini menghasilkan draf 1 meliputi penyusunan tes, pemilihan media, dan desain awal.

\section{Pengembangan (Develop)}

Tujuan dari tahap ini untuk menghasilkan draf buku ajar yang telah direvisi berdasarkan masukan para pakar dan data yang diperoleh dari uji coba skala terbatas dan uji coba skala luas. Kegiatan pada tahap ini meliputi validasi buku ajar dan uji coba buku ajar.

Buku ajar yang dikembangkan terlebih dahulu divalidasi oleh dua orang validator ahli (pakar) untuk mendapatkan saran perbaikan sekaligus merupakan penilaian para ahli terhadap rancangan buku ajar (draf 1) dengan mempertimbangkan komponen-komponen yang divalidasi oleh ahli meliputi contents, language, presentations, figure properness (Linuwih et al., 2017). Hasil validasi dari para ahli kemudian direvisi sehingga diperoleh draf 2 buku ajar yang siap dilakukan uji coba skala terbatas pada kelompok kecil yang terdiri atas 10 orang peserta didik semester 4 . Uji coba skala terbatas ini bertujuan untuk mengetahui keterbacaan, dan kejelasan materi. Hasil ujicoba skala terbatas kemudian direvisi dan menghasilkan draf 3 yang siap dilakukan uji coba skala luas. Kegiatan uji coba skala luas dilakukan pada peserta didik Semester 1 Tahun Akademik 2018/2019 di Prodi DIII Refraksi Optisi (RO) STIKES HAKLI Semarang.

Pengambilan data dilakukan melalui :

a. Tes evaluasi hasil belajar diberikan sebelum dan sesudah peserta didik melakukan kegiatan pembelajaran.

b. Pengamatan aktivitas peserta didik berbasis Soft-skills dengan menggunakan lembar observasi yang dilakukan selama proses pembelajaran berlangsung dengan buku ajar yang dikembangkan.

c. Kuesioner digunakan untuk proses validasi isi terhadap buku ajar oleh pakar dan mengetahui respons peserta didik terkait kepraktisan buku ajar yang digunakan.

d. Wawancara digunakan untuk proses survey awal.

Analisis data tes dan kuesioner menggunakan statistik deskriptif dengan bantuan SPSS 21, sedangkan data temuan dari wawancara dan observasi menggunakan kualitatif deskriptif.

\section{Hasil Penelitian dan Pembahasan}

Penelitian ini menghasilkan buku ajar yang telah dikembangkan melalui tahapan validasi ahli, uji efektifitas dan analisis kepraktisan.

\section{Hasil Validasi Buku ajar}

Validasi ahli terhadap buku ajar Fisika Optik berbasis Soft-skills yang telah disusun pada tahap perancangan. Penilaian ahli dilakukan berpedoman pada lembar penilaian validator. Berdasarkan hasil validasi ahli terhadap buku ajar yang dikembangkan diperoleh rekapitulasi hasil berupa skor penilaian buku ajar dengan nilai 32 dan termasuk dalam kategori baik dan dinyatakan Valid. Hasil rekapitulasi skor penilaian buku ajar dapat dilihat pada Tabel 1.

Tabel 1. Rekapitulasi Skor Penilaian Buku Ajar

\begin{tabular}{|c|c|c|c|c|c|}
\hline \multirow{3}{*}{$\begin{array}{l}\text { Kompone } \\
\mathrm{n} \quad \text { Buku } \\
\text { Ajar }\end{array}$} & \multirow{2}{*}{\multicolumn{2}{|c|}{$\begin{array}{c}\text { Validato } \\
\mathrm{r}\end{array}$}} & \multirow{3}{*}{$\begin{array}{l}\text { Rata } \\
\text {-rata }\end{array}$} & \multirow{2}{*}{$\begin{array}{l}\text { Skor } \\
\text { Mak }\end{array}$} & \multirow[t]{3}{*}{ Ket } \\
\hline & & & & & \\
\hline & 1 & 2 & & s & \\
\hline $\begin{array}{l}\text { Konten } \\
\text { (isi) }\end{array}$ & 31 & 31 & 31 & 40 & \multirow{5}{*}{$\begin{array}{l}\text { Dapat } \\
\text { digunaka } \\
\mathrm{n} \text { dengan } \\
\text { sedikit } \\
\text { revisi } \\
\text { dan } \\
\text { Valid }\end{array}$} \\
\hline Bahasa & 31 & 31 & 31 & 40 & \\
\hline Presentasi & 31 & 33 & 32 & 40 & \\
\hline $\begin{array}{l}\text { Kecocoka } \\
\text { n gambar }\end{array}$ & 34 & 34 & 34 & 40 & \\
\hline Total & & & 32 & 40 & \\
\hline
\end{tabular}


Interval penilaian buku ajar dapat dilihat pada Tabel 2.

Tabel 2. Interval Penilaian Buku Ajar

\begin{tabular}{|c|c|c|}
\hline SKOR & NILAI & Keterangan \\
\hline $\begin{array}{c}33 \leq n \leq \\
40\end{array}$ & $\begin{array}{c}\text { Sangat } \\
\text { Baik }\end{array}$ & $\begin{array}{l}\text { Dapat digunakan } \\
\text { tanpa revisi dan } \\
\text { Valid }\end{array}$ \\
\hline $\begin{array}{c}26 \leq \mathrm{n} \leq \\
32\end{array}$ & Baik & $\begin{array}{l}\text { Dapat digunakan } \\
\text { dengan sedikit revisi } \\
\text { dan Valid }\end{array}$ \\
\hline$\underset{25}{18 \leq \mathrm{n}} \leq$ & $\begin{array}{c}\text { Cukup } \\
\text { Baik }\end{array}$ & $\begin{array}{l}\text { Dapat digunakan } \\
\text { tetapi banyak revisi }\end{array}$ \\
\hline $\begin{array}{c}10 \leq \mathrm{n} \leq \\
17\end{array}$ & $\begin{array}{l}\text { Tidak } \\
\text { Baik }\end{array}$ & $\begin{array}{l}\text { Belum dapat } \\
\text { digunakan sehingga } \\
\text { masih perlu direvisi } \\
\text { dan dikonsultasikan }\end{array}$ \\
\hline
\end{tabular}

Berdasarkan interval penilaian buku ajar dapat disimpulkan bahwa buku ajar termasuk dalam kategori "Baik". Kesimpulan yang diberikan adalah buku ajar dapat digunakan meskipun masih ada sedikit revisi. Berdasarkan kesimpulan dan masukan validator tersebut, selanjutnya dilakukan revisi terhadap buku ajar. Revisi buku ajar tergambar pada Tabel 3.

Tabel 3. Revisi Buku Ajar

\begin{tabular}{|c|c|c|}
\hline No & Catatan Validator & Tindak Lanjut \\
\hline 1. & $\begin{array}{l}\text { Supaya ditambah } \\
\text { peta konsep dan } \\
\text { tujuan } \\
\text { pembelajaran di } \\
\text { bagian awal. }\end{array}$ & $\begin{array}{l}\text { Menambahkan peta } \\
\text { konsep dan tujuan } \\
\text { pembelajaran dalam } \\
\text { buku ajar. }\end{array}$ \\
\hline 2. & $\begin{array}{l}\text { Dibagian akhir } \\
\text { akhir supaya } \\
\text { ditambah latihan } \\
\text { soal dan daftar } \\
\text { pustaka. }\end{array}$ & $\begin{array}{l}\text { Menambahkan } \\
\text { latihan soal dan } \\
\text { daftar pustaka di } \\
\text { bagian akhir dari } \\
\text { buku ajar. }\end{array}$ \\
\hline
\end{tabular}

Buku ajar yang sudah dikembangkan berdasarkan hasil validasi ahli sudah dinyatakan valid. Buku ajar tersebut (Gambar 2) diujicobakan untuk mengetahui keefektifan dan kepraktisan dari pengembangan buku ajar materi Fisika Optik berbasis Soft-skills dapat mengotimalkan hasil belajar dan aktivitas mahasiswa.

\section{Hasil Uji Keefektifan Buku Ajar}

Uji keefektifan buku ajar meliputi 1) analisis tes hasil belajar mahasiswa dan 2) pengamatan aktivitas mahasiswa berbasis softskills.

\section{Analisis Tes Hasil Belajar Mahasiswa.}

Hasil analisis tes hasil belajar diberikan sebelum dan sesudah mahasiswa melakukan kegiatan pembelajaran. Hasil tes belajar mahasiswa dapat dilihat pada Tabel 4.

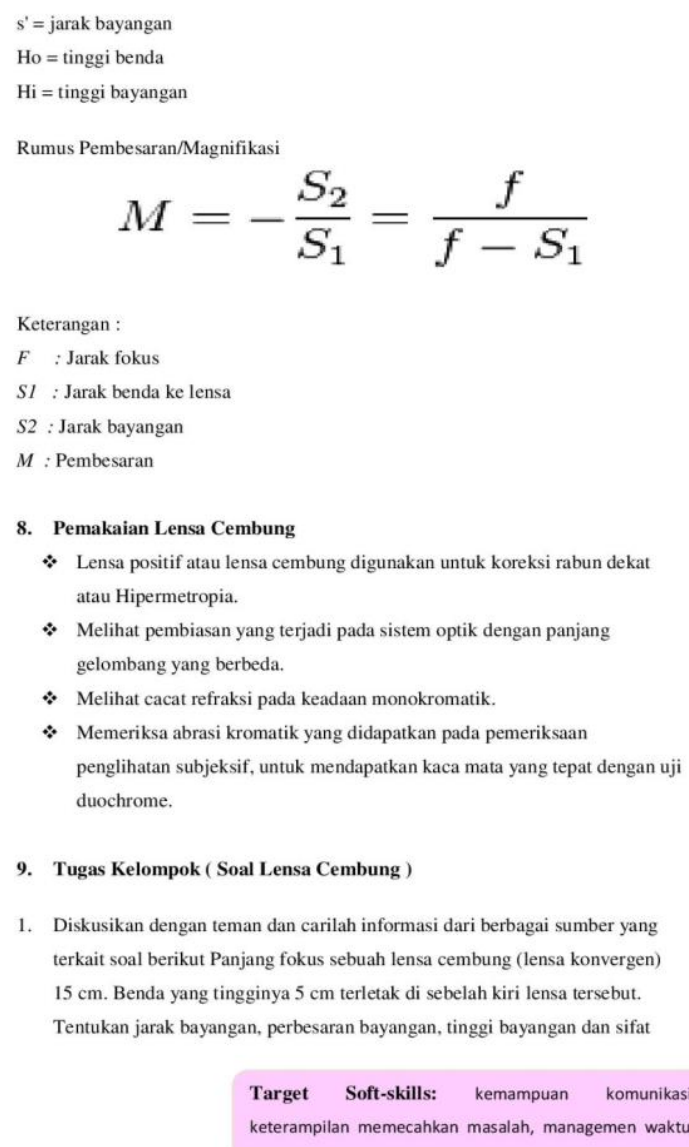

1. Diskusikan dengan teman dan carilah informasi dari berbagai sumber yang terkait soal berikut Panjang fokus sebuah lensa cembung (lensa konvergen) $15 \mathrm{~cm}$. Benda yang tingginya $5 \mathrm{~cm}$ terletak di sebelah kiri lensa tersebut. Tentukan jarak bayangan, perbesaran bayangan, tinggi bayangan dan sifat keterampilan memecahkan masalah, managemen wakt

Gambar 2. Lembar Buku Ajar Fisika Optik Berbasis Soft-skills

Tabel 4. Analisis Tes Hasil Belajar Mahasiswa

\begin{tabular}{|c|c|c|c|c|c|}
\hline \multirow{2}{*}{ No. } & \multirow{2}{*}{$\begin{array}{c}\text { Hasil } \\
\text { Analisis }\end{array}$} & \multicolumn{2}{|c|}{$\begin{array}{c}\text { Kelas } \\
\text { Kontrol }\end{array}$} & \multicolumn{2}{|c|}{$\begin{array}{c}\text { Kelas } \\
\text { Eksperimen }\end{array}$} \\
\hline & & $\begin{array}{l}\text { Pre } \\
\text { test }\end{array}$ & $\begin{array}{l}\text { Post } \\
\text { Test }\end{array}$ & Pre & $\begin{array}{l}\text { Post } \\
\text { Test }\end{array}$ \\
\hline 1. & Nilai & & & & \\
\hline 2. & & 36,67 & 46,67 & 30,00 & 70,00 \\
\hline 3. & $\begin{array}{l}\text { Tertinggi } \\
\text { Nilai }\end{array}$ & 66,67 & 86,67 & 63,33 & 90,00 \\
\hline & Rata-rata & 59,07 & 72,22 & 49,81 & 79,07 \\
\hline
\end{tabular}

Berdasarkan Tabel 4 bahwa tes hasil belajar dari kelas eksperimen yang menggunakan buku ajar fisika optik berbasis Soft-skills lebih baik dibandingkan kelas kontrol.

2. Pengamatan Aktivitas Mahasiswa Berbasis Soft-Skills. 
Pengamatan aktivitas mahasiswa berbasis Soft-skills dengan menggunakan lembar observasi yang dilakukan selama proses pembelajaran berlangsung dengan buku ajar yang dikembangkan. Analisa hasil pengamatan keaktifan siswa diperoleh skor rata-rata hasil keaktifan siswa dengan perangkat pembelajaran Fisika Optik sebesar 3,4. Kriteria interval skor penilaian aktivitas siswa dilihat pada Tabel 5 .

Tabel 5 Kriteria Interval Skor Penilaian

Aktivitas Siswa Berbasis Soft-Skills

\begin{tabular}{cc}
\hline Interval & Kriteria \\
\hline $3,3 \leq \mathrm{n} \leq 4$ & Sangat aktif \\
$2,6 \leq \mathrm{n} \leq 3,2$ & Aktif \\
$1,8 \leq \mathrm{n} \leq 2,5$ & Cukup aktif \\
$1 \leq \mathrm{n} \leq 1,7$ & Tidak aktif \\
\hline
\end{tabular}

Hasil analisis aktivitas siswa berbasis Soft-skills adalah 3,4. Berdasarkan kriteria interval skor penilaian aktivitas siswa berbasis Soft-skills termasuk dalam kriteria sangat aktif. Data aktivitas siswa berbasis Soft-skills diambil dari hasil pengamatan dalam lembar pengamatan yang diamati oleh 3 orang pengamat yaitu peneliti itu sendiri dan 2 orang dosen di prodi RO. Aktivitas siswa yang paling tinggi skornya adalah aktivitas siswa yang berkaitan dengan kemampuan komunikasi, keterampilan memecahkan masalah. Sedangkan aktivitas siswa yang berkaitan dengan managemen waktu perlu ditingkatkan.

Kepraktisan Pengembangan Buku Ajar Fisika Optik Berbasis Soft-Skills

Indikator yang menyatakan bahwa buku ajar yang dikembangkan praktis adalah mahasiswa sangat aktif dan bertanggung jawab dalam proses pembelajaran, memberikan kesempatan pada mahasiswa untuk mampu mengeluarkan pendapat dan menghargai pendapat orang lain, hasil belajar mahasiswa lebih baik, memberikan kesempatan pada setiap mahasiswa untuk aktif dalam diskusi.

Hasil analisis respons siswa menunjukan $87,3 \%$ memberikan respons positif yang menyatakan bahwa pembelajaran yang menggunakan bahan ajar fisika optik berbasis Soft-skills bisa memotivasi mereka untuk terus belajar dan siswa merasa senang selama proses pembelajaran berlangsung. Hasil tersebut menunjukan bahwa buku ajar yang dikembangkan termasuk pada kategori praktis.

\section{Kesimpulan}

Penerapan buku ajar Fisika Optik berbasis Softskills dapat berpengaruh secara signifikan pada hasil belajar dan aktivitas mahasiswa. Saran dari hasil penelitian ini adalah buku ajar yang telah dikembangkan dapat dipergunakan pada kelas lain atau sekolah lain yang memiliki karakteristik yang sama/setara dengan kelas eksperimen dan dapat diterapkan pada materi pokok bahan lain.

\section{Daftar Pustaka}

Deepublish, T. J. N. (2016). Rahasia Menulis Buku Ajar (1st ed.). Yogyakarta: DEEPUBLISH.

Hanifah, U. (2014). Pentingnya Buku Ajar yang Berkualitas Pembelajaran Bahasa Arab Umi Hanifah *. Jurnal At-Tajdid, 3(1), 99-121.

Hartiti, T. (2013). Peningkatan Soft-skill Perawat melalui Kepemimpinan Ransformasional Kepala Ruang pada RS Swasta di Semarang. Jurnal Manajemen Keperawatan -Persatuan Perawat Nasional Indonesia, 1(2), 115-123.

Ismail, G. (2007). Soft-skill untuk menjual diri di Dunia Kerja. Berita Universitas Muhammadiyah Yogyakarta.

Junrat, S., Jenphop, C., Suravee, R., \& Kanokorn, S. (2014). Soft-skills for University Library Staff in Thailand. Procedia - Social and Behavioral Sciences, 112 (Iceepsy 2013), 1027-1032. https://doi.org/10.1016/j.sbspro.2014.01.1 265

Linuwih, S., Lurinda, N., \& Fianti. (2017). Developing Physics Textbook based on Cognitive Conflict for Deeper Conceptual Understanding and Better Characters. IOP Conf. Series: Journal of Physics: Conf. Series 824 (2017) 012014, 9(1). https://doi.org/10.1088/17426596/755/1/011001

Musa, F., Mufti, N., Latiff, R. A., \& Amin, M. M. (2012). Project-based Learning (PjBL): Inculcating Soft skills in 21st Century Workplace. Procedia - Social and Behavioral Sciences, 59(2006), 565-573. https://doi.org/10.1016/j.sbspro.2012.09.3 
15

Muslich, M. (2010). Text book writing: Dasardasar pernahaman, penulisan, dan pemakaian buku teks. Yogyakarta: ArRuzz Media.

Selçuk, G. S., \& Çalişkan, S. (2010). A smallscale study comparing the impacts of problem-based learning and traditional methods on student satisfaction in the introductory physics course. Procedia Social and Behavioral Sciences, 2(2), 809-813.

https://doi.org/10.1016/j.sbspro.2010.03.1

08

Supriadi, D. (2001). Anatomi Buku Sekolah di Indonesia. Yogyakarta: Adi Cita.

Trianto. 2012. Mendesain Model Pembelajaran Inovatif Progresif. Jakarta: Kencana Persada Media Group.

Widarto, Pardjono, \& Noto, W. (2013). Pengembangan Model Pembelajaran Soft skills dan Hard Skills untuk Siswa SMK. Journal.Uny.Ac.Id Fakultas Teknik Universitas Negeri Yogyakarta, (1), 1-20.

Widhiarso, W. (2009). Evaluasi Soft-skills dalam Pembelajaran. 